\title{
DRAINAGE WELLS \\ AS AN INTEGRAL PART OF A DEEP DEWATERING SYSTEM IN SZCZERCÓW FIELD \\ IN THE BEŁCHATÓW LIGNITE MINE***
}

\section{INTRODUCTION}

The lignite extraction can be performed in the Bełchatów Lignite Mine after prior dewatering of the rock mass with the use of large-diameter dewatering wells distributed in the form of external and inner barriers (parallel orientation). This type of dewatering system allows for safe extraction of lignite, however residual waters in the overburden may locally create hazard. These are rain waters infiltrating into the rock mass, and which, due to the complex geological build of the deposit and disturbed system of layers, were not overtaken by wells belonging to the primary dewatering system. They are removed through the existing and newly drilled exploration wells, which are converted into drainage wells. Such wells are used for removing waters suspended in permeable overburden and gravitationally moved to the lower absorbing layers, from where they are directed to the primary dewatering system wells and then to the surface water courses $[5,8]$. The applied enhancement of the dewatering system used in the lignite deposit in Szczerców Field significantly improves the safety of mining works conducted in this place.

* PGE Górnictwo i Energetyka Konwencjonalna Spółka Akcyjna, Oddział Kopalnia Węgla Brunatnego Bełchatów Rogowiec

** AGH University of Science and Technology, Faculty of Drilling, Oil and Gas, Krakow, Poland

*** Work performed within the statutory research program of AGH No. 11.11.190.555 


\section{AN OUTLINE \\ OF GEOLOGICAL AND HYDROGEOLOGICAL CONDITIONS IN THE AREA OF BEŁCHATÓW LIGNITE DEPOSIT}

Bełchatów lignite deposit is localized in the Kleszczów Trough, which is a narrow WE tectonic structure formed on the Mesozoic basement and constituting a local lowering. The length of the trough totals to about $38.5 \mathrm{~km}$, and its width ranges from 1.5 to $2.0 \mathrm{~km}$. The natural division into Bełchatów Field and Szczerców Field results from the presence of a small salt dome Dębina in its central part, constituting a local elevation of the Permian salt deposit [2, 3, 7, 8]. Geologically, this area is built of the Permian, Triassic, Jurassic, Cretaceous, Tertiary and Quaternary strata. Groundwaters create three aquifer complexes: overburden, sub-coal and Mesozoic with numerous developed hydraulic communication pathways. The water-bearing Mesozoic complex is composed of fractured limestones, marls and breccia. The overburdens and sub-coal are mainly composed of sands, gravel and their mix $[1,2,12]$. A generalized geological cross-section of the Bełchatów Lignite Deposit is presented in Figure 1.

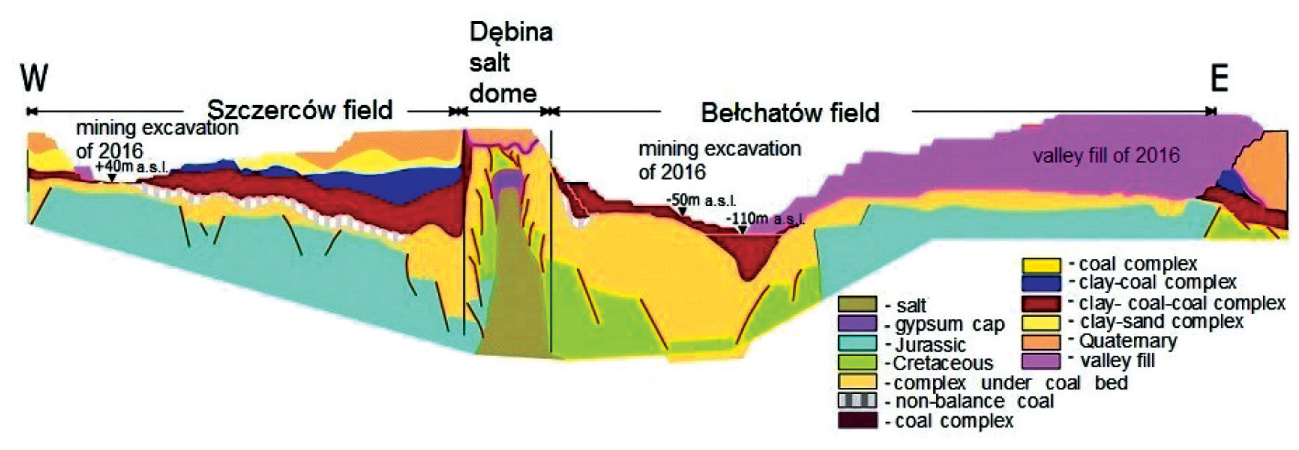

Fig. 1. Geological cross-section (WE) through Bełchatów lignite deposit [12]

\section{DEWATERING OF ROCK MASS IN THE BEŁCHATÓW LIGNITE MINE}

Both open-pit excavations in Bełchatów Lignite Mine, i.e. Bełchatów and Szczerców Field were applied a deep dewatering system - primary and auxiliary. In Szczerców Field the primary deep dewatering system consists of large-diameter dewatering wells, drilled from the surface to a depth of 40 to $350 \mathrm{~m}$. These wells were distributed in barriers, i.e. WE lines running parallel to the edges of the designed cut slopes, at a distance from about 80 to $150 \mathrm{~m}$. The auxiliary system consists of wells which are to support the operation of the primary deep dewatering system. These are $[8,9,10]$ : 
- Pump-dewatering wells for sub-coal complexes, which are used to lower the stress in aquifers under the coal bed and safely lower the groundwater level below the lowermost extraction level. The lowering of water level below the assumed value guarantees safe mining operations and eliminates watering of the foot of the valley fill, which allows to locate relatively close to the excavation itself.

- Pump-dewatering wells and absorbing wells for overburden levels, to remove the residual and suspended waters, which due to the complicated geological structure and disturbed system of layers, were not removed by the primary dewatering system.

In view of the various purposes of the dewatering wells, the primary and auxiliary wells in dewatering systems can be distinguished (Fig. 2) [4, 6, 12]:

- external barriers localized in the north and south wing in the Szczerców Field (Kleszczów Trough), beyond the excavation area,

- inner permanent barriers are localized in the north and south wing of the Szczerców Field (Kleszczów Trough) within the excavation area,

- inner barriers localized in the overburden,

- auxiliary dewatering system (pump-dewatering wells, drainage wells and absorbing wells).

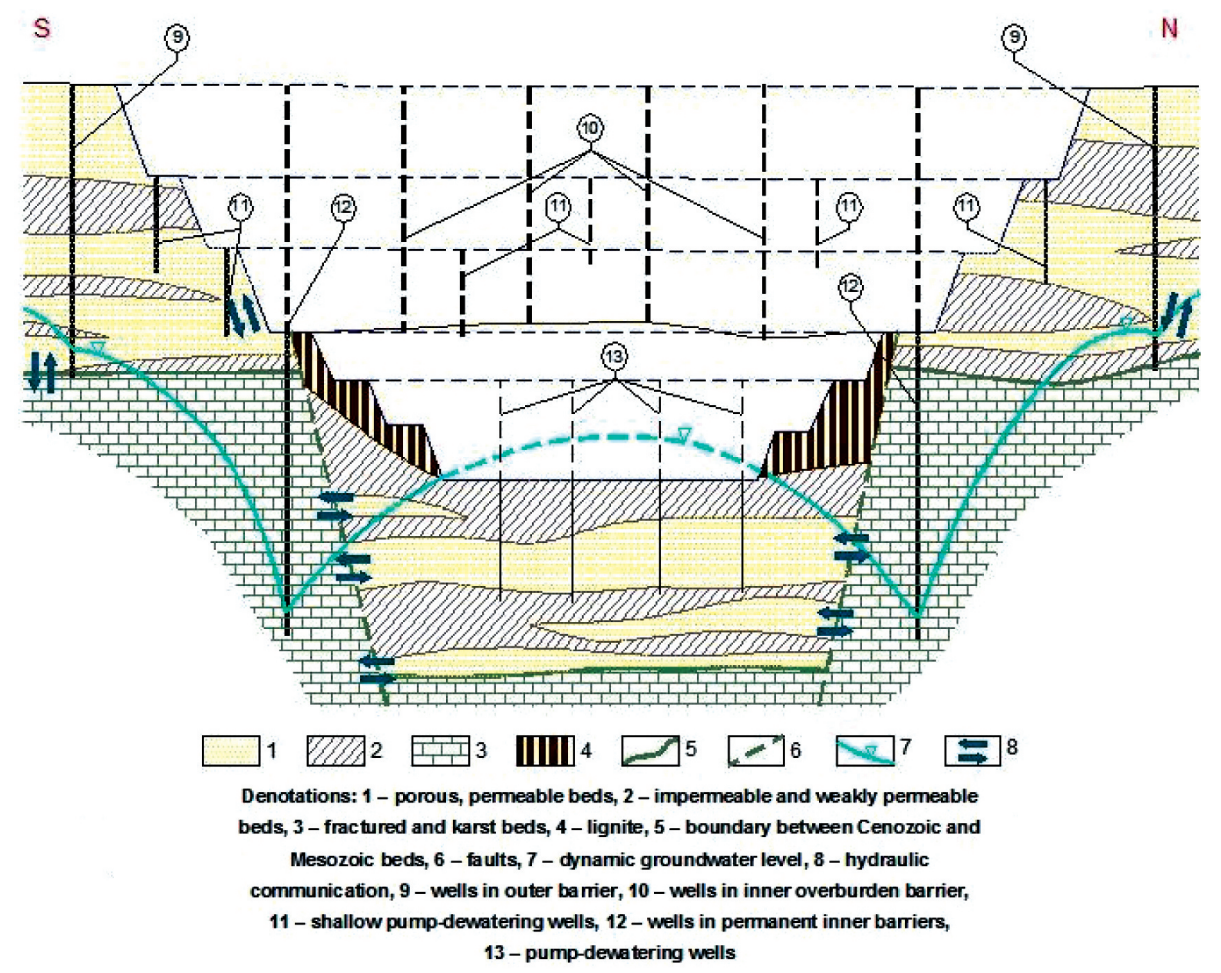

Fig. 2. Schematic of deep dewatering system in Szczerców Field [3, 7] 


\section{A CONCEPT OF INCREASING THE EFFICIENCY OF DEEP DEWATERING OPERATIONS WITH THE GRAVITY DRAINAGE METHOD}

A very important problem which affects the efficiency of dewatering of overburden of coal deposit and safety of operation of excavator machines is the primary and secondary watering of overburden extraction layers in the Szczerców Field. Three basic causes of such watering have been distinguished on the basis of many years observations $[1,6,7,9]$ :

- Groundwaters present in large erosion troughs, filled with permeable material, synclines, structural and tectonic troughs. Watering is caused by the insufficient drainage by wells belonging to the primary dewatering system as well as complicated and strongly disturbed system of aquifers.

- Groundwaters appearing in closed, insulated lenses and disturbed sand layers within impermeable series. The resources of these groundwaters are limited as they are not supplied from the neighboring areas.

- Groundwaters suspended in the top of the impermeable layers in the areas of small deleveling of these layers. The magnitude of watering is significantly conditioned by infiltration of rain waters.

The primary and secondary residual waters are removed with the use of pump-dewatering and absorbing wells (ca. $30 \mathrm{~m}$ of depth) from the auxiliary dewatering system, performed additionally on the basis of the current recognition of the watering level. Despite the large number of such wells, waters in the overburden still posed problems and the extraction could not be performed safely. This has led to search for alternative solutions and analysis of possibility of using of exploration drainage wells drilled with the dry method to a depth of ca. $60 \mathrm{~m}$ as well as cored exploration well for rock mass dewatering $[8,9]$.

The exploration wells realized by June 2015 allowed for a detailed recognition of the lithology, thickness and spatial distribution of drilled permeable and impermeable layers in the entire over burden profile. The primary dewatering system gave a direct insight into the zones of watered zones or zones to be potentially watered by infiltrating rain waters. Moreover, when accounting for the present depth of dynamic water table, the results of drilling wells of various purpose allowed for recognizing potential absorbing layers. Exploration wells were only an additional element of gravitational removal of water to dewatered lower layers. For this reason the task of the realized exploration wells can be extended by additional drainage functions. 
Waters removed from the watered overburden layers to the lowermost absorbing layers are pumped by active dewatering wells from the primary dewatering system. The wells frequently play the drainage function for a couple of years, when the works on overburden and coal extraction are performed, till the time the wells are completely closed. An idea schematic of drainage wells in Bełchatów Lignite Mine is presented in Figure 3.

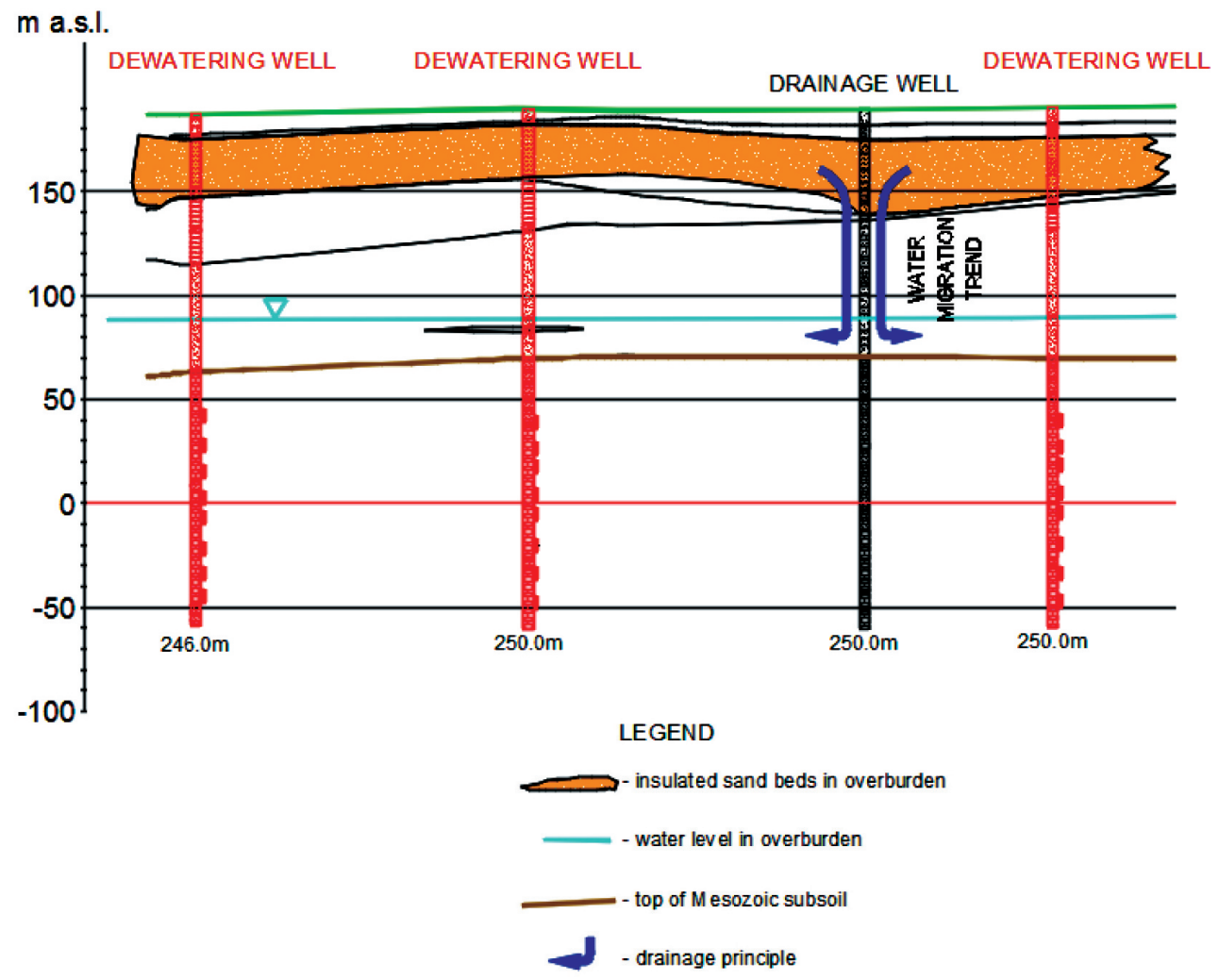

Fig. 3. Idea schematic of drainage wells on the background of an exemplary hydrogeological profile (W2-E2)

The use of exploration wells for draining locally watered overburden layers should considerably reduce the number of performed wells in the auxiliary dewatering system, shorten the range of electrical infrastructure supplying power to pump aggregates, minimize the number of pump aggregates and works connected with the build and maintenance of pipelines discharging water from wells. An exemplary drainage well is presented in Figure 4. 


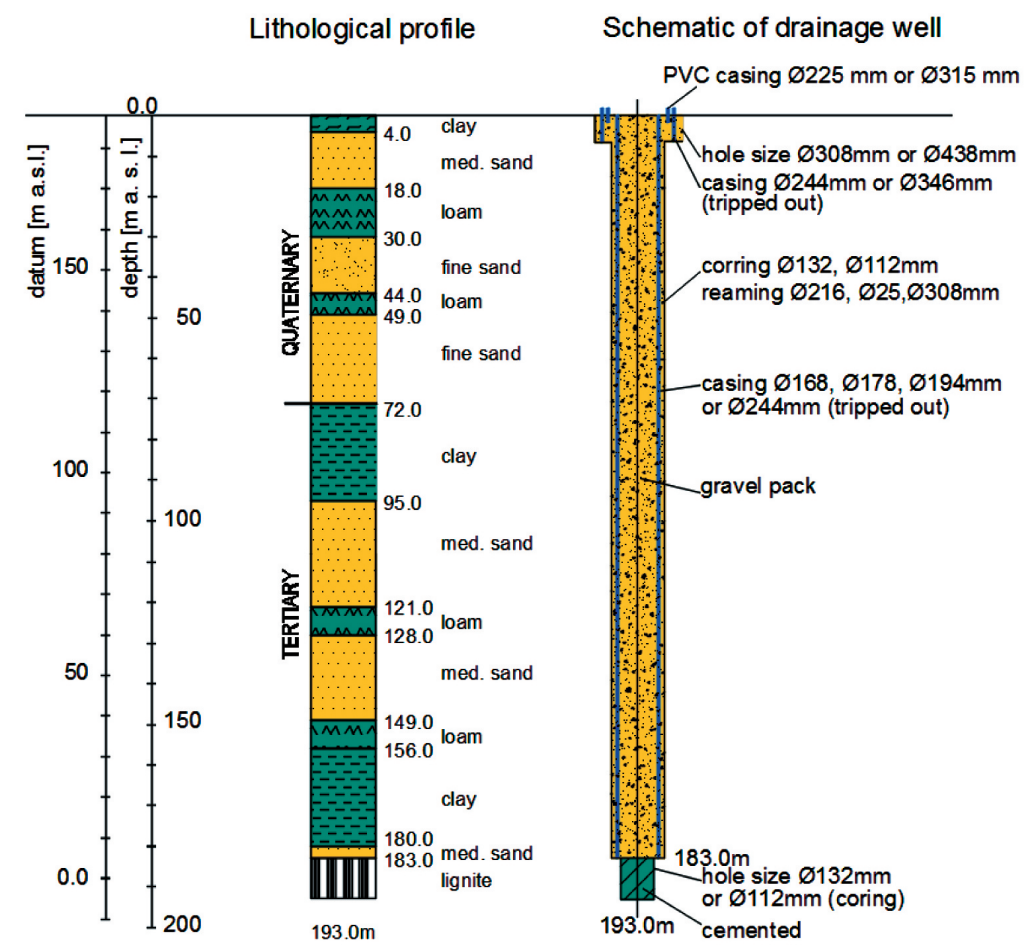

Fig. 4. Exemplary drainage well [11]

\section{SCOPE OF REALIZATION OF DRAINAGE WELLS IN THE BEŁCHATÓW LIGNITE MINE}

The realization of drainage wells in the Szczerców Field began in June 2015 and the following wells have been performed in the Bełchatów Lignite Mine so far:

2015: - absorbing wells, 21 wells of total length of $1217 \mathrm{~m}$,

- exploration wells converted into drainage wells, 12 wells of total length of $3382 \mathrm{~m}$,

2016: - absorbing wells, 37 wells of total length of $2275 \mathrm{~m}$,

- exploration wells converted into drainage wells, 27 wells of total length of $6374 \mathrm{~m}$.

The depth of these wells ranged from 45 to $443 \mathrm{~m}$. After filling the drainage wells with gravel (to $20 \mathrm{~mm}$ of grain size), they were tested for absorbing capacity, i.e. they were watered and then the volume of absorbed water in a unit of time was measured for each of them. Presently, the absorbency of drainage wells is always assessed at the stage of 
commissioning. The methods of analyzing absorbing capacity of wells and clear criteria of their hydraulic parameters evaluation are conducted in the Bełchatów Lignite Mine.

In 2016 the absorbency tests were conducted in 59 drainage wells. The minimum absorbency defined during the experiments equaled to $12 \mathrm{l} / \mathrm{min}$, and maximum to $324 \mathrm{l} / \mathrm{min}$. The average gravitational dewatering ability by one drainage well from watered overburden layers totals to about $116.5 \mathrm{~m}^{3} /$ day [12]. Figure 5 illustrates a statistical distribution of absorbing abilities of drainage wells in 2016.

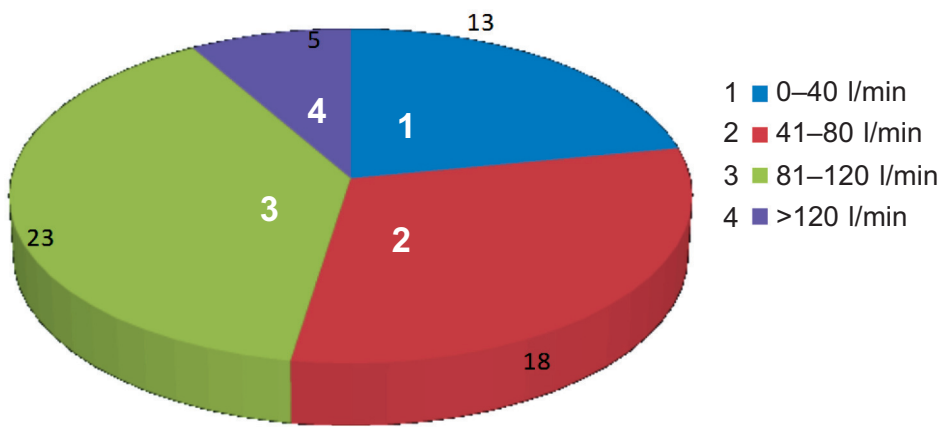

Fig. 5. Absorbing ability of drainage wells realized in Szczerców Field in 2016

A list of drainage wells performed in 2016 on the background of the other types of drillings in the Bełchatów Lignite Mine is presented in Figure 6.

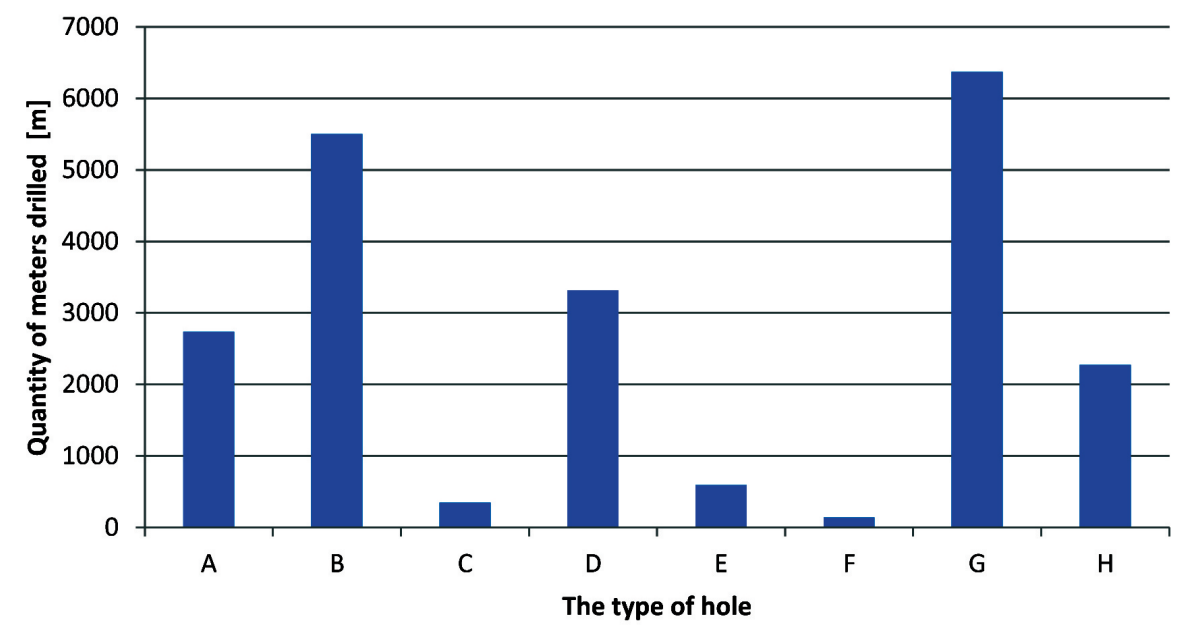

A - Deep dewatering wells, B - Dewatering overburden wells, C - Auxiliary dewatering wells, D - Monitoring wells within excavation site, E - Control monitoring wells, F - Monitoring wells within excavation site, $\mathrm{G}$ - Cored drainage wells, $\mathrm{H}$ - Drainage wells performed with dry method to ca. $60 \mathrm{~m}$ of depth

Fig. 6. List of all drillings performed in Bełchatów Lignite Mine in 2016 


\section{PRELIMINARY EVALUATION OF RESULTS OF IMPLEMENTATION OF DRAINAGE WELLS AS AN ELEMENT OF DEEP DEWATERING SYSTEM}

The main reason for implementing a new solution was increasing the efficiency of the deep dewatering system with special emphasis on increasing the efficiency of liquidation of watering of the operational levels with primary and secondary waters. Presently, i.e. over 1.5 a year after the drainage wells started to be performed, the first conclusions on the obtained results can be drawn. The first areas for the future drainage wells are gradually cut in the Szczerców Field with the machinery. The first signs of improving hydrogeological situation in Level I and II in the forefield of the excavation can be observed. In the second half of 2015 the drilling the auxiliary dewatering system in the overburden started to gradually by significantly lower. This trend was even more visible in 2016. The range of these drillings resulted from the recognition of the watering level in the forefield of working levels of the overburden, which is performed with the use of shallow exploration drilled with the dry method. The watering level in these areas in the analyzed time considerably lowered as compared to the state of the first half of 2015 and before that time. Accordingly, the necessity of apply dewatering actions in the immediate neighborhood of the excavation decreased. This proves the efficiency of the implemented solutions and functionality of drainage wells, which reduce primary and secondary watering of the overburden, gravitationally discharging water to the lower aquifers.

\section{SUMMARY}

The implementation of drainage wells is a very important step on the way of perfecting the deep dewatering system in the Bełchatów Lignite Mine. This is a significant contribution of respective services of the Bełchatów Lignite Mine in optimization of the deep dewatering program. The present state-of-the-art and experience are a result of a 40-year engineer's practice in dewatering systems. New solutions in the form of drainage wells influence the cost and course of preparatory works preceding excavation operations. Moreover, drainage wells, being new elements of the dewatering system in the open-pit conditions, will allow for optimizing the dewatering system and obtaining of the required advancement of excavation works.

\section{REFERENCES}

[1] Kuszneruk J., Wojtkowiak B.: Ocena efektywności odwadniana ztoża węgla brunatnego - Pole Betchatów - systemem wielkośrednicowych studni głębinowych w poszczególnych okresach funkcjonowania kopalni. Sympozjum Naukowe „25 lat doświadczeń Bełchatów Lignite Mine”. 2000. 
[2] Macuda J., Gasiński J.: Proekologiczna bariera odwadniająca wokót wysadu solnego „Dębina”w KWB „Betchatów”. Wiertnictwo Nafta Gaz, t. 17, 2000.

[3] Macuda J., Gasiński J., Krokosz J.: Technologia wiercenia głębokich studni odwadniających na przykładzie wierceń realizowanych w obrębie wysadu solnego „Dębina”. Oficyna Wydawnicza P.Wr, Prace Naukowe Instytutu Górnictwa Politechniki Wrocławskiej, z. 112. Seria: Konferencje: 44/2005.

[4] Macuda J. i in.: Opracowanie techniki i technologii prowadzenia wierceń $w$ warunkach utworów skrasowiatych i silnego krasu na Polu Szczerców. Praca niepublikowana, Wydział Wiertnictwa, Nafty i Gazu, AGH Kraków, 2010.

[5] Motyka J. i in.: Wpływ głębokiej eksploatacji węgla brunatnego na zmiany środowiska wodnego w rejonie Kopalni „Betchatów”. Górnictwo i Geoinżynieria, R. 31. z. 2, 2007.

[6] Poltegor-Projekt: Pole Betchatów i Pole Szczerców. Ocena wyprzedzenia robót górniczych i robotami odwodnieniowymi dla Pola Betchatów i Szczerców - warunki bieżace, określenie parametrów na przyszłość. Wrocław, 2007.

[7] Poltegor-Projekt: Hydrogeologiczne warunki odwadniania złoża węgla brunatnego Betchatów - etap 16 wraz z analiza robót wiertniczych za okres 1.01 .2014 do 31.12.2014 - Pole Bełchatów i Pole Szczerców. Wrocław, 2013.

[8] Poltegor-Projekt: Hydrogeologiczne warunki odwadniania złoża węgla brunatnego Betchatów - etap 17 wraz z analiza robót wiertniczych za okres 1.01.2015 do 31.12.2015 - Pole Bełchatów i Pole Szczerców. Wrocław, 2015.

[9] Poltegor-Projekt: Pole Szczerców. Otwory rozpoznawcze - drenażowe - etap 16. Wrocław, 2015.

[10] Poltegor-Projekt: Pole Szczerców. Operatywne otwory rozpoznawcze - etap 16. Wrocław, 2015.

[11] Karty otworów hydrogeologicznych wykonywanych w Bełchatów Lignite Mine.

[12] Materiały archiwalne Bełchatów Lignite Mine. 